Article

\title{
In Vitro Comparison of the Anti-Proliferative Effects of Galenia africana on Human Skin Cell Lines
}

\author{
Banele Ndlovu ${ }^{1} \mathbb{D}$, Maryna De Kock ${ }^{1}$, Jeremy Klaasen ${ }^{1} \mathbb{D}$ and Farzana Rahiman ${ }^{1,2, *}$ \\ 1 Department of Medical Bioscience, University of the Western Cape, Cape Town 7535, South Africa; \\ 3470783@myuwc.ac.za (B.N.); mdekock@uwc.ac.za (M.D.K.); jklaasen@uwc.ac.za (J.K.) \\ 2 Skin Research Lab, Department of Medical Biosciences, University of the Western Cape, Robert Sobukwe Rd, \\ Bellville, Cape Town 7535, South Africa \\ * Correspondence: frahiman@uwc.ac.za
}

\section{check for}

updates

Citation: Ndlovu, B.; De Kock, M.; Klaasen, J.; Rahiman, F. In Vitro Comparison of the Anti-Proliferative Effects of Galenia africana on Human Skin Cell Lines. Sci. Pharm. 2021, 89, 12. https://doi.org/10.3390/ scipharm89010012

Received: 30 December 2020

Accepted: 4 February 2021

Published: 25 February 2021

Publisher's Note: MDPI stays neutral with regard to jurisdictional claims in published maps and institutional affiliations.

Copyright: (c) 2021 by the authors. Licensee MDPI, Basel, Switzerland. This article is an open access article distributed under the terms and conditions of the Creative Commons Attribution (CC BY) license (https:// creativecommons.org/licenses/by/ $4.0 /)$.

\begin{abstract}
Malignant melanoma is the major cause of skin cancer-related deaths. Surgery in combination with radiotherapy, immunotherapy or chemotherapy is used to eradicate cancer cells, however, this treatment option is limited by the tolerance of the surrounding healthy tissue. The extracts from Galenia africana have been shown to possess anti-cancer flavonoid compounds and can be a safer and cost-effective alternative treatment. The study aimed to compare the anti-proliferative effects of G. africana on human skin cells (HaCaT) and human malignant melanoma cells (A375). The cells were exposed to various concentrations of the G. africana extract at different times. In vitro assays were employed to determine cell viability and cytotoxicity. Hoechst 33342 staining was performed to observe the nuclear changes, including apoptosis. G. africana significantly reduced the cell viability of the A375 cells in a dose and time-dependent manner, while having no effect on the HaCaT cells. The A375 cells displayed nuclear condensation, brightly stained nuclei and nuclear fragmentation indicative of apoptosis. This suggests a clinical rationale for the use of G. africana as a potential anti-melanoma agent offering efficacy and low toxicity. This study provides new insights for future work on investigating the utilization of G. africana in malignant melanoma treatment.
\end{abstract}

Keywords: skin cancer; Galenia africana; A375; HaCaT; anti-proliferation; cytotoxicity

\section{Introduction}

The human skin is constantly exposed to ultraviolet radiation (UVR) from sunlight, which causes cell damage resulting in skin cancer [1]. Melanoma is the most aggressive malignant skin cancer with high metastatic abilities. It poses a major clinical challenge for oncologists and continues to increase in incidence worldwide [2-4]. Melanoma accounts for nearly $73 \%$ of skin-cancer related deaths with an $18 \%$ chance of a 5 -year survival rate for patients suffering from metastatic melanoma [2,3]. Melanoma arises from melanocytes, pigment-generating cells found within the basal layer of the epidermis of the skin, hair and eyes [1,4]. A recent study confirmed a strong association between the incidence of melanoma and groups of individuals who are constantly exposed to high UVR emphasizing the critical role UVR plays in melanoma tumorigenesis [5]. The UVR acts as a mutagen by forming mutations such as irreparable inefficiencies and errors between covalent links of two adjacent pyrimidines, cytosine and thymine, as well as pyrimidine dimers in the deoxyribonucleic acid (DNA) [5,6]. The irreparable mutation causes the cells to grow uncontrollably and become cancerous [7].

There are various stages of melanoma. The early stages can be predominantly treated with a combination of surgery and other therapies including immuno-, biologic-, radio- and chemotherapy $[4,8,9]$. The majority of these chemotherapeutic agents cause toxic effects, restricting their usage [1,7]. The advanced stages of melanoma are most lethal due to the high metastatic potential, as the melanoma disseminates to affect areas not commonly affected in 
other cancer types [1]. These metastatic lesions extend to the surrounding epidermis, superficial dermis, as well as the gastrointestinal tract $[1,5]$. There are no standard treatments for metastatic melanoma due to the increased majority of melanomas ultimately developing resistance to both systemic and conventional cancer therapies eventually requiring the use of a combination of treatment options $[1,2,4,8]$. The administration of therapies such as chemotherapy, radiation and hormone therapy is also usually restricted to specialized centers that are not easily accessible in developing countries [8]. Furthermore, the systemic therapies of metastatic melanoma are associated with significant toxicities, and extensive comorbidities such as autoimmune conditions including myositis, peripheral neuropathy, autoimmune pancreatitis and autoimmune aplastic anaemia [10]. Chemotherapy treatments have also given rise to well-known cutaneous adverse events with reports of skin toxicity observed in $44 \%$ of patients, specifically pruritus and rashes reported in approximately $20 \%$ of patients [11]. Although therapeutic strategies have improved through the years, the prognosis remains poor and the disease remains incurable in many patients that have metastatic risk and drug-resistant tumours [3,4]. Considering the adverse effects of the current treatment strategies, there is a need for safe alternative treatments with little to no adverse side effects [12-14].

There is a need for more effective anti-cancer agents that can be well-tolerated by patients, are non-toxic to healthy cells, reduce the metastasis of the malignant disease, as well as be cost-effective and readily available in poor communities [14]. Research continues to develop novel agents for the treatment of melanoma and to control its metastasis. At present, natural products and their bioactive compounds or phytochemicals are recognized as being the most promising and novel strategy to prevent, inhibit or reverse the processes of carcinogenesis [15]. The use of herbal medicines has widely increased over the years, with about $64 \%$ of the world's population known to use herbal medicines [16]. There are reports on plant metabolites known to target programmed cell death mechanisms [17]. Phytochemicals are considered effective chemo-preventative agents due to their antioxidant, anti-mutagenic, anti-carcinogenic and carcinogen detoxification properties. They act on several target molecules that modulate cellular processes such as inflammation, immunity, cell cycle progression and apoptosis [15].

Galenia africana (G. africana), commonly known as "kraalbos" is a medicinal plant widespread in regions of South Africa but predominantly found in the Namaqualand as well as the Western and Southern Karoo. There have been reports on the various traditional uses of G. africana by indigenous communities, including its use in the treatment of coughs, wounds, tuberculosis, skin infections, inflammation of the eyes and venereal sores $[18,19]$. G. africana has numerous secondary phytochemical flavonoids which provide the plants with various biochemical properties and health benefits [20,21]. Flavonoids are a group of plant-derived compounds that have significant medical health beneficial properties such as anti-cancerous, anti-bacterial, anti-viral, anti-inflammatory, anti-oxidant and anti-fungal activities [20,22,23]. Ticha et al. [21] and Vries et al. [24] identified 5,7dihydroxyflavonone (pinocembrin) as a major flavonoid compound in ethanol extracts of G. africana. Pinocembrin has been shown to possess anti-cancer activity against various cancer cells $[25,26]$. Despite the evidence of the extract's anti-cancer activity, there is still limited information available on the anti-proliferative effects of G. africana on malignant melanoma in vitro. The present study aimed to compare the anti-proliferative effect of G. africana on different cell lines namely normal human skin cells (HaCaT) and human malignant melanoma cells (A375).

\section{Materials and Methods}

\subsection{Preparation of Galenia africana Plant Extract}

The commercially prepared $20 \%$ G. africana extract was obtained from Parceval Pharmaceuticals (Pty) Ltd., (Wellington, South Africa). Following the preliminary unpublished work of Ngu'ni [27], the extract was dried using a commercial vacuum drying chamber to dry the ethanolic extract under reduced pressure at a temperature of $50^{\circ} \mathrm{C}$. This was 
done to dehydrate the extract, removing any excess absorbed solvent and water to attain a crystal-form of the extract that was used in subsequent experiments. For each experiment, the crystal-form of the extract was reconstituted in complete Dulbecco's Modified Eagle's Medium (DMEM, Lonza, Cape Town, South Africa) to generate a 3\% stock solution and stored at $4{ }^{\circ} \mathrm{C}$. Fresh $3 \%$ G. africana extract was prepared with the commencement of every new experiment. For all the experiments, the HaCaT and A375 cells were treated with 100, 200, 500, and $1000 \mu \mathrm{g} / \mathrm{mL}$ concentrations of G. africana dried ethanolic extract for 24, 48 and $72 \mathrm{~h}$. The cells containing only supplemented media were used as controls. Due to the removal of the ethanol from the extract, a positive control for the extract was deemed unnecessary.

\subsection{Cell Lines and Cell Culture}

The A375 cells were obtained from the University of Cape Town (UCT) as a gift from the UCT Skin and Hair Centre. The HaCaT cell line was purchased from Cell Line Service $\mathrm{GmbH}$ (Eppelheim, Germany). Both cell lines were seeded and propagated in DMEM supplemented with 10\% heat-inactivated foetal bovine serum (HI-FBS, Hyclone, Little Chalfont, UK), antibiotic penicillin $(100 \mathrm{U} / \mathrm{mL})$ and streptomycin $(100 \mathrm{mg} / \mathrm{mL})(\mathrm{GIBCO}$ BRL, Grand Island, NY, USA) and maintained in a humidified incubator with $5 \% \mathrm{CO}_{2}$ at $37^{\circ} \mathrm{C}$. Cell treatments were always carried out $24 \mathrm{~h}$ after plating and subsequently treated with 100, 200, 500 and $1000 \mu \mathrm{g} / \mathrm{mL}$ concentrations of $G$. africana ethanolic extract for 24, 48 and $72 \mathrm{~h}$.

\subsection{Determination of Cell Proliferation and Viability}

The 3-(4,5-dimethylthiazol-2-yl)-2,5-diphenyltetrazolium bromide (MTT) assay was used for the determination of the G. africana effect on the cell viability as previously described [28]. The assay determines cell viability by measuring the enzymatic reduction of yellow tetrazolium to purple formazan via cellular mitochondria. The A375 and HaCaT cells were seeded into 96-well tissue test plates (Greiner Bio-one, Kremsmunster, Austria) at a seeding density of $1 \times 10^{4}$ cells / well and allowed to adhere overnight. Cells were treated with the various concentrations of the G. africana ethanolic extract for 24, 48 and $72 \mathrm{~h}$ to evaluate the influence of exposure time on the cytotoxic effect of the extract. Cells without the extract treatment served as controls. At the end of each exposure period, the toxicity level was assessed via MTT assay (stock solution $5 \mathrm{mg} / \mathrm{mL}$ : PBS) with the formazan solvent being DMSO and detected using a microplate spectrophotometer (Glomax Multi Detection System, Promega, Madison, WI, USA) at $560 \mathrm{~nm}$.

\subsection{Trypan Blue Exclusion Assay}

The trypan blue exclusion assay was used to confirm the results obtained from the MTT assay as well as to determine cell proliferation. This assay was performed accordingly with minor modifications to the seeding densities as earlier described [17]. Exponentially growing A375 and HaCaT cells were seeded into 6-well culture plates (Greiner Bio-one) at a seeding density of $1 \times 10^{4}$ cells/well in complete DMEM media and grown to attachment overnight. Thereafter, cells were treated with the various concentrations of the G. africana ethanolic extract in biological triplicate for 24, 48 and $72 \mathrm{~h}$. For live quantification, cultured cells were trypsinated stained with trypan blue (0.4\%) (Sigma-Aldrich, St. Louis, MO, USA) and subsequently counted using a haemocytometer.

\subsection{Determination of Cytotoxicity}

The lactate dehydrogenase (LDH) assay was used to determine cellular cytotoxicity. $\mathrm{LDH}$ is a cytosolic enzyme present in the cells that are released into the cell culture medium upon damage to the plasma membrane [29]. LDH activity was measured using a LDHcytotoxicity kit (CyQuant ${ }^{\mathrm{TM}}$ kit, ThermoFisher Scientific, Eugene, OR, USA) and was performed as per the manufacturer's instructions. Briefly, the A375 and HaCaT cells were plated in 96-well plates at a seeding density of $10^{4}$ cells/well. After $24 \mathrm{~h}$, the various 
concentrations of the G. africana ethanolic extract were added and the cells were incubated for the different exposure times. At the end of each time point, the LDH activity was measured using a microplate reader (Glomax Multi Detection System, Promega), at test wavelengths of $490 \mathrm{~nm}$ and $680 \mathrm{~nm}$, respectively. According to the manufacturer, the $680 \mathrm{~nm}$ (background signal from instrument) absorbance values were subtracted from the $490 \mathrm{~nm}$ absorbance values. Control wells included cells in complete media, cells in serumfree media, Spontaneous LDH activity and Maximum LDH activity control. Percentage cytotoxicity was calculated using the formula in Equation (1):

Cytotoxicity $\%=\left(\frac{(\text { Extract treated LDH activity }- \text { Spontaneous LDH activity })}{\text { (Maximum LDH activity }- \text { Spontaneous LDH activity })}\right) \times 100$

\subsection{Nuclear Morphological Changes}

To explore whether the decrease in A375 cell viability after treatment was a result of apoptosis, Hoechst 33342 staining was performed to detect nuclear morphological changes associated with apoptosis. Near confluent layers of each cell line were grown on sterile coverslips placed in tissue culture plates for $24 \mathrm{~h}$, where after the samples were treated and incubated with different concentrations of the G. africana ethanolic extract for 24, 48 and $72 \mathrm{~h}$. The sample coverslips were subsequently fixed in $80 \%$ methanol and washed with 1 $\mathrm{mL}$ of PBS. After fixation, the fluorescent stain was performed for live DNA staining as well as nuclear imaging. Briefly, $500 \mu \mathrm{L}$ of Hoechst 33,342 stain (stock solution $1 \mathrm{mg} / \mathrm{mL}$ : PBS) (Sigma-Aldrich) was added to each plate and incubated at room temperature for $20 \mathrm{~min}$. The stain was then removed and each plate was washed with $500 \mu \mathrm{L}$ of distilled water $\left(\mathrm{dH}_{2} \mathrm{O}\right)$. A fluorescence microscope (360 4i Nikon, Tokyo, Japan) was used to examine the nuclear morphology at $20 \times$ magnification. The ImageJ software (National Institutes of Health (NIH), Bethesda, MD, USA) was used to analyse and process the images for better resolution.

\subsection{Statistical Analysis}

Using the SPSS 14.0 software (SPSS, Chicago, IL, USA), the data were reported as mean and standard deviation from triplicate measurements. Statistical significance of differences among groups was evaluated using one-way analysis of variance (ANOVA) and the Student $t$-test where appropriate. Additionally, in the cell viability assay, the median inhibitory concentration $\mathrm{IC}_{50}$ was calculated using Microsoft excel software (Microsoft Corporation, Redmond, WA, USA). The statistical significance was accepted at the level of $p<0.05$ compared to the negative control (untreated cells).

\section{Results}

\subsection{Effect of Galenia africana on Cell Viability}

G. africana exhibited a significant $(p<0.05)$ time and dose-dependent reduction in A375 cell numbers. After 48 and 72 h, 25\% and 60\% of the A375 cells respectively, exposed to $500 \mu \mathrm{g} / \mathrm{mL}$ G. africana had died. Cells exposed to $1000 \mu \mathrm{g} / \mathrm{mL}$ for 48 and $72 \mathrm{~h}$ showed a reduction of $38 \%$ and $74 \%$, respectively (Figure $1 \mathrm{~A}$ ). In contrast, the G. africana ethanolic extract appeared to display a biphasic pattern when exposed to the HaCaT cell line after $48 \mathrm{~h}$. For this time point, a significant $11 \%$ increase was observed at $200 \mu \mathrm{g} / \mathrm{mL}(p<0.05)$, suggesting that lower doses $(100$ and $200 \mu \mathrm{g} / \mathrm{mL})$ could potentially increase cell growth, while higher concentrations (500 and $1000 \mu \mathrm{g} / \mathrm{mL}$ ) reduced cell viability in all expose times (Figure 1B). 


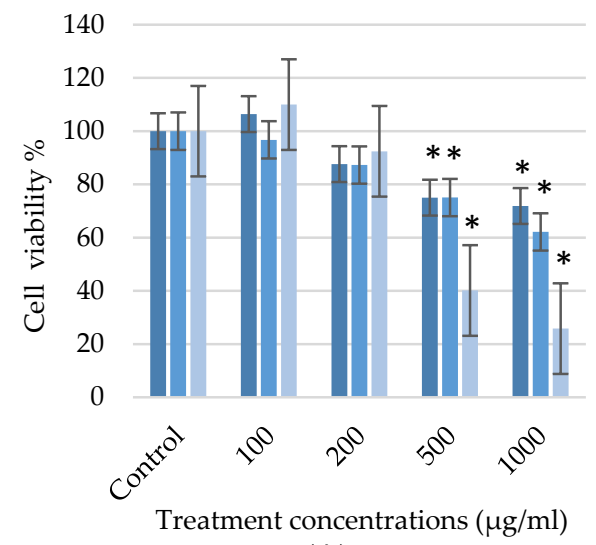

(A)

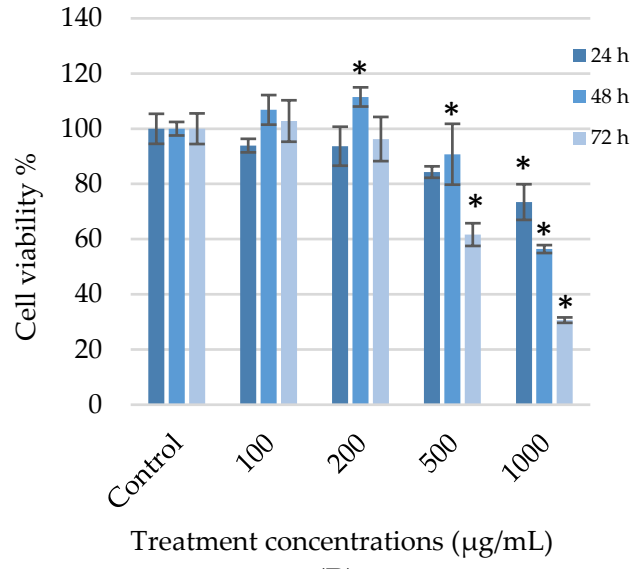

(B)

Figure 1. Cell viability of the human melanoma (A375) cells (A) and normal human skin (HaCaT) cells (B) treated with 100; 200; 500 and $1000 \mu \mathrm{g} / \mathrm{mL}$ of the G. africana ethanolic extract for 24, 48 and $72 \mathrm{~h}$ determined using the 3-(4,5-dimethylthiazol-2-yl)-2,5-diphenyltetrazolium bromide (MTT) assay. Data represent the mean $\pm \mathrm{SD}, n=3$, where the * indicates statistical significance at level $p<0.05$ vs. the control.

Table 1 shows the $\mathrm{IC}_{50}$ values for each cell line, it is notable the extract was able to reduce cell viability of $\mathrm{A} 375$ cells with an $\mathrm{IC}_{50}$ value of $572.70 \pm 0.06 \mu \mathrm{g} / \mathrm{mL}$ and $\mathrm{HaCaT}$ $\mathrm{IC}_{50}$ value of $711.04 \pm 0.055 \mu \mathrm{g} / \mathrm{mL}$ after longer exposure $(72 \mathrm{~h})$. Results show that the longer exposure of G. africana to the A375 cell line, the greater the reduction in cells viability, while longer exposure to normal skin cells $(\mathrm{HaCaT})$ has negligible cytotoxic effects on the cells.

Table 1. Cell reduction and selectivity of the ethanolic extracts of Galenia africana at different exposure times.

\begin{tabular}{ccc}
\hline & Reduction in Cell Viability $\left(\mathrm{IC}_{\mathbf{5 0}}\right.$ Value $\left.\pm \mathbf{S D}, \boldsymbol{\mu g} / \mathbf{m L}\right)$ \\
\hline Exposure Times (h) & A375 & HaCaT \\
\hline $\mathbf{2 4}$ & $1438.68 \pm 0.09$ & $1893.89 \pm 0.02$ \\
$\mathbf{4 8}$ & $1258.98 \pm 0.077$ & $1102.21 \pm 0.006$ \\
$\mathbf{7 2}$ & $572.70 \pm 0.06$ & $711.04 \pm 0.055$ \\
\hline
\end{tabular}

$\mathrm{IC}_{50}$ : Represents the concentration of extract that is required for $50 \%$ inhibition of cell viability. SD; Standard deviation.

The trypan blue exclusion assay confirmed the results obtained from the MTT assay. After A375 and HaCaT cells were exposed to the various concentrations of G. africana for 24,48 and $72 \mathrm{~h}$, the extract exhibited a significant reduction in viability in a time and dosedependent manner with a significant decrease $(p<0.05)$ at the higher concentrations (500 and $1000 \mu \mathrm{g} / \mathrm{mL}$ ) for both cell lines after 48 and $72 \mathrm{~h}$. At lower doses (100 and $200 \mu \mathrm{g} / \mathrm{mL}$ ), both cell lines showed a slight decrease in viability but with no significance (Figure 2).

\subsection{Potential Cytotoxic Effect of G. africana}

Figure 3 confirm the previous results. No cytotoxicity at the lower concentrations (100 and $200 \mu \mathrm{g} / \mathrm{mL}$ ) for both cell types, was observed. The percentage cytotoxicity in A375 cells exposed for $72 \mathrm{~h}$ showed a $55 \%$ and $59 \%$ significant $(p<0.05)$ increase at the 500 and $1000 \mu \mathrm{g} / \mathrm{mL}$ dosages, respectively (Figure $3 \mathrm{~A}$ ). The HaCaT cells only had a significant $(p<0.05)$ increase in cytotoxicity at the highest concentration $(1000 \mu \mathrm{g} / \mathrm{mL})$ of G. africana ethanolic extract after $72 \mathrm{~h}$ where a $63 \%$ increased cytotoxicity was observed. (Figure 3B). 


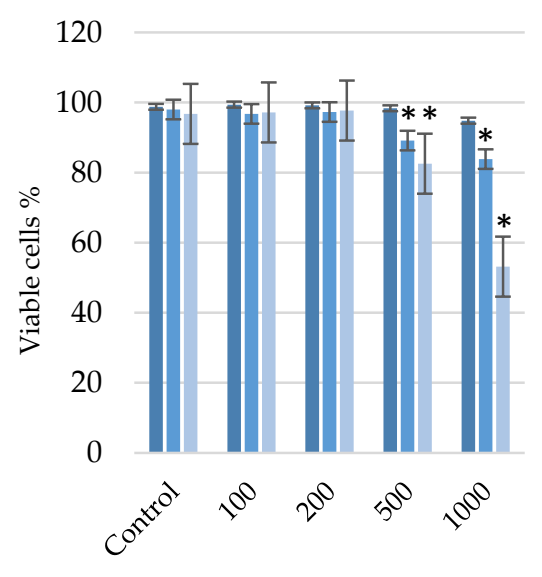

Treatment concentration $(\mu \mathrm{g} / \mathrm{ml})$

(A)

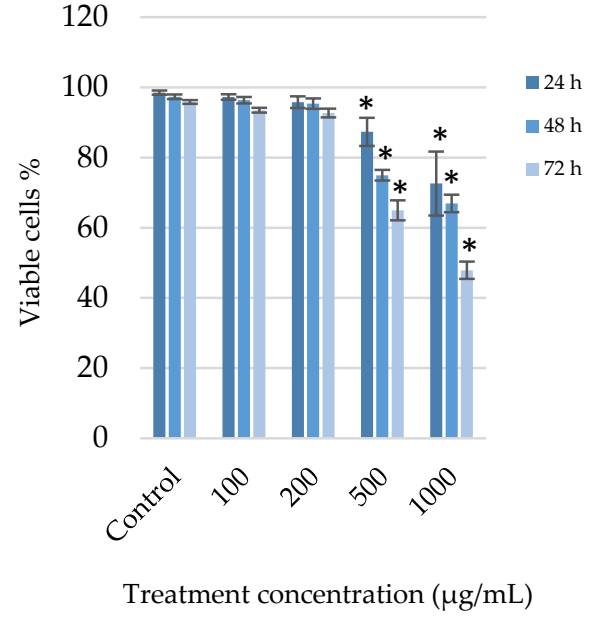

(B)

Figure 2. After the human melanoma (A375) cells (A) and normal human skin (HaCaT) cells (B) were treated with 100; 200; 500 and $1000 \mu \mathrm{g} / \mathrm{mL}$ concentrations of $\mathrm{G}$. africana ethanolic extract for 24,48 and $72 \mathrm{~h}$, the cell proliferation and viability was determined using trypan blue exclusion assay. Data represent the mean $\pm \mathrm{SD}, n=3$, where the * indicates statistical significance at level $p<0.05$ vs. the control.

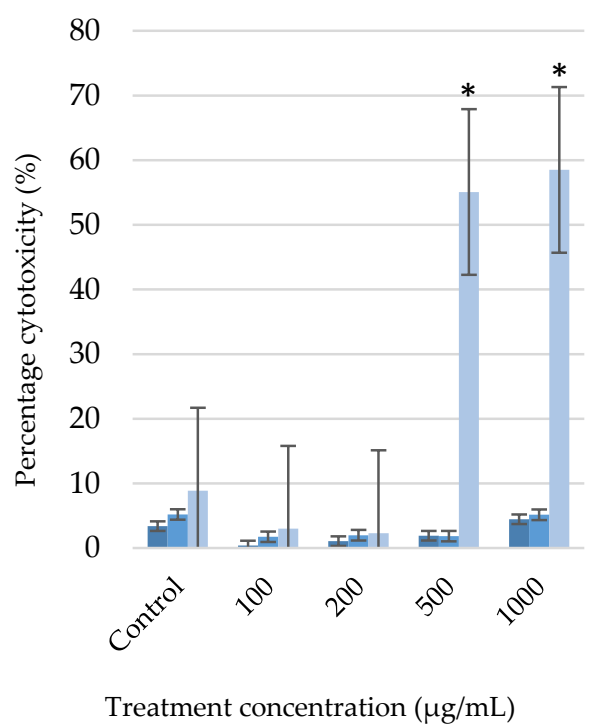

(A)

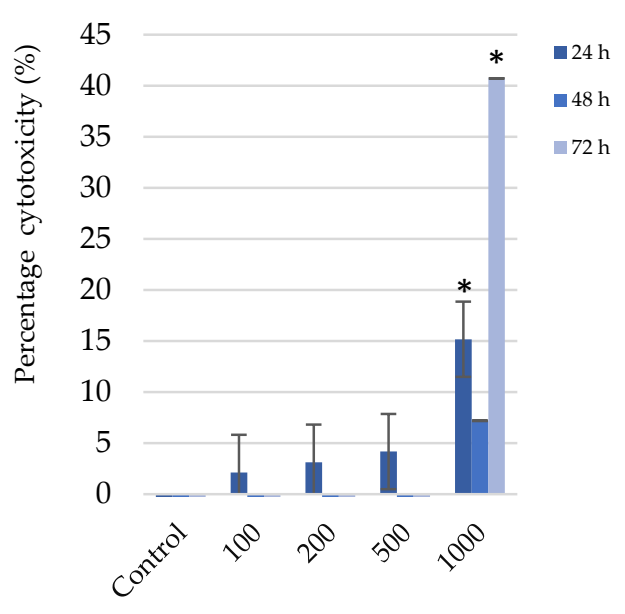

Treatment concentrations $(\mu \mathrm{g} / \mathrm{mL})$

(B)

Figure 3. After the human melanoma (A375) cells (A) and normal human skin (HaCaT) cells (B) were treated with 100; 200; 500 and $1000 \mu \mathrm{g} / \mathrm{mL}$ concentrations of G. africana ethanolic extract for 24, 48 and $72 \mathrm{~h}$, the cell cytotoxicity was determined using lactate dehydrogenase (LDH) assay. Data represent the mean $\pm \mathrm{SD}, n=3$, where the ${ }^{*}$ indicates statistical significance at level $p<0.05$ vs. the control.

\subsection{Effects of G. africana on Nuclei Morphology}

Apoptosis is a form of cell death that involves vesicle formation, nuclear membrane blebbing, and chromosome condensation [17]. The HaCaT and A375 cell lines were exposed to various concentrations of the G. africana ethanolic extract and the nuclear morphological changes were detected by staining with Hoechst and fluorescence microscopy (Figure 4). A375 cells exposed to 500 and $1000 \mu \mathrm{g} / \mathrm{mL}$ show irregularly shaped and brightly stained nuclei including nuclear condensation and fragmentation (Figure 4A). At lower concentrations (100 and $200 \mu \mathrm{g} / \mathrm{mL}$ ) mitotically active cells and no nuclear changes could be observed 
(Figure 4A). The HaCaT cells, exposed to the various concentrations of G. africana ethanolic extract showed no or very little effect on the morphology of the nuclei with only a few apoptotic features observed at the cells exposed to the highest concentration $(1000 \mu \mathrm{g} / \mathrm{mL})$ after 48 and $72 \mathrm{~h}$ (Figure 4B).
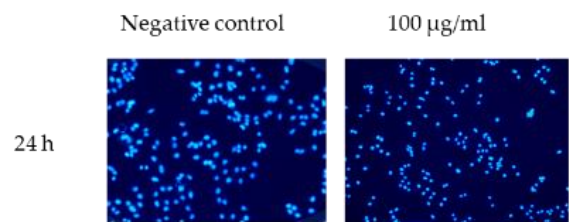

$200 \mu \mathrm{g} / \mathrm{ml}$
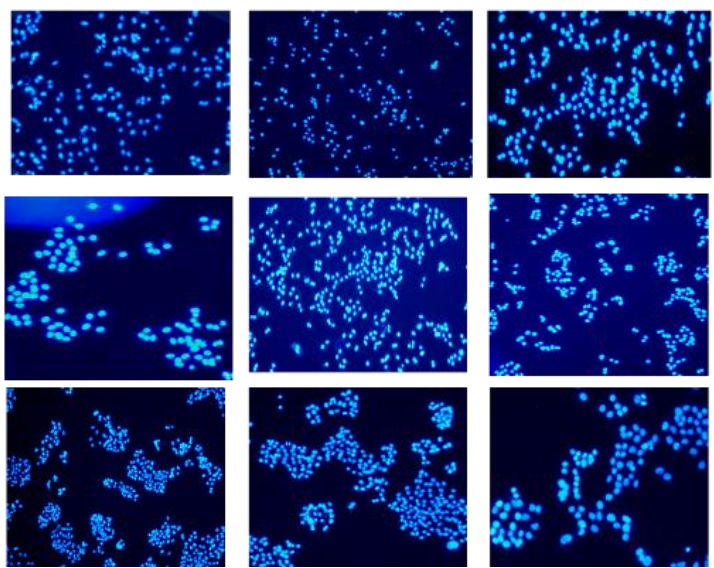

$72 \mathrm{~h}$

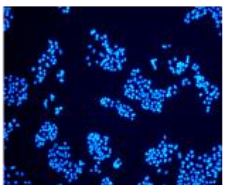

Negative control

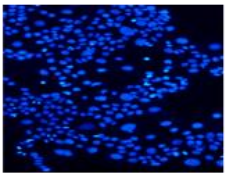

$48 \mathrm{~h}$
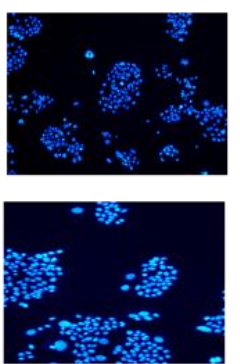

$100 \mu \mathrm{g} / \mathrm{ml}$
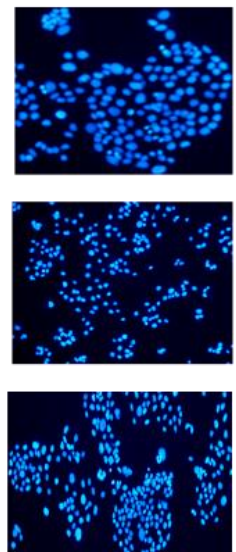
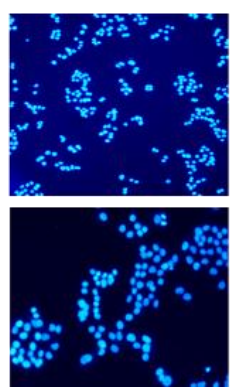

(A)
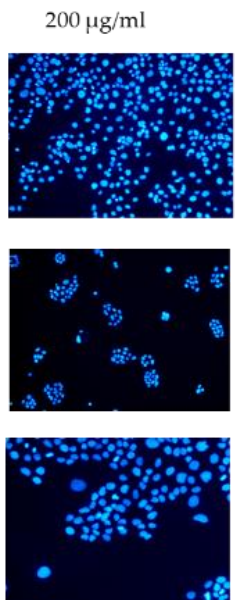

(B)
$500 \mu \mathrm{g} / \mathrm{ml}$
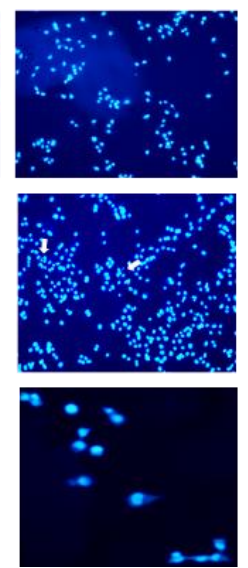

$500 \mu \mathrm{g} / \mathrm{ml}$
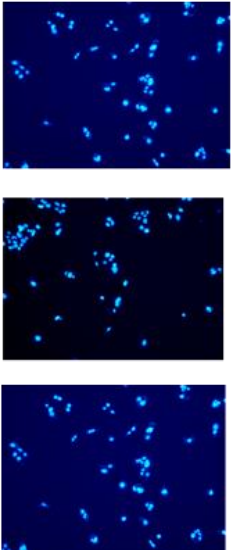

$1000 \mu \mathrm{g} / \mathrm{ml}$
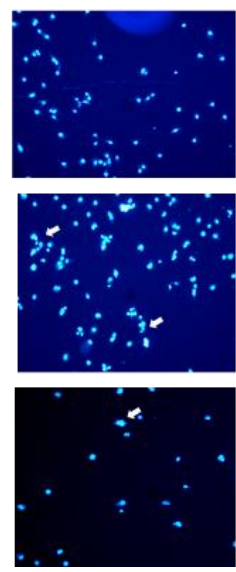

$1000 \mu \mathrm{g} / \mathrm{ml}$
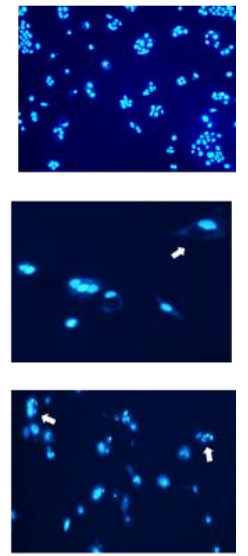

Figure 4. Nuclear changes of the human melanoma (A375) cells (A) and normal human skin (HaCaT) cells (B) by the G. africana ethanolic extract. After treatment with 100;200; 500 and $1000 \mu \mathrm{g} / \mathrm{mL}$ the cell lines were stained with Hoechst for 24,48 and $72 \mathrm{~h}$. The photographs under a fluorescence microscope were shown $(20 \times)$. Arrows show apoptotic features such as nuclear shrinkage, chromatin condensation, irregularly shaped nuclear and nuclear fragmentation.

\section{Discussion}

Galenia africana has been used in traditional medicine to treat various ailments, most interestingly to treat diseases of the skin. It is also currently used in the skincare industry as a topical application in products such as lotions, decoctions and wound dressings [30]. A study by Van Wyk et al. [31] reports on the anecdotal evidence on traditional uses of G. africana, where a weak infusion of the extract was used to treat rheumatism or the extract was boiled to treat wounds. However, there has been little scientific advancement made in this field with regards to the effect of G. africana on cancer and even more so on chemo-resistance or chemoprevention of human malignant melanoma skin cancer. Chemoprevention refers to the use of naturally occurring compounds for cancer prevention and control. Chemo-preventive drugs derived from medicinal plants, particularly those 
that exert anti-proliferative effects on cancer, are being sought after in different regions of the world [32]. This is because these medicinal plants contain flavonoids which are a group of plant metabolites that have great potential as anti-cancer agents inhibiting metastasis, while also inducing apoptosis in cancer cells [33].

The G. africana ethanol extracts have been reported to contain flavonoid compounds which could potentially activate programmed cell death mechanisms by acting as prooxidants and inducing mitochondria-mediated apoptosis in cancer cells [17,20,21]. A recent study by Mohamed et al. [34] reported that the ethanolic extracts of G. africana had antiproliferative properties and induced apoptosis against breast cancer cells (MCF-7 and MDA-MB-231). Previous work has also investigated the plant's immunomodulatory potential and its anti-tuberculosis effects [21,31,35].

In the present study of human melanoma cells, results showed that G. africana has the potential to be a natural chemotherapeutic agent. This could be due to its non-toxic and specific mechanism of discriminating between cell types by targeting melanoma cancer cells, while not being cytotoxic to the healthy cells at low concentrations of use. The cell viability results show that $G$. africana seemed to reduce the cell viability of the A375 melanoma cells with an $\mathrm{IC}_{50}$ value of $572.70 \pm 0.06 \mu \mathrm{g} / \mathrm{mL}$ after $72 \mathrm{~h}$ of exposure. According to our analyses, the higher concentrations (500 and $1000 \mu \mathrm{g} / \mathrm{mL}$ ) had a reduction in cell viability in all exposure times. This shows that the cell viability of A375 cells was affected in a time and dose-dependent manner. A similar study also reported that G. africana could reduce cell viability of malignant breast cancer cell lines MCF-7 and MDA-MB-231 ( $\mathrm{IC}_{50}$ values of 114.0 and $130.5 \mu \mathrm{g} / \mathrm{mL}$ ) in a dose-dependent manner, respectively [34]. This further substantiating the extract's anti-proliferative effects. When comparing the cell viability effects of the G. africana to normal HaCaT cells, the extract had negligible cytotoxic effects $\left(\mathrm{IC}_{50}\right.$ $711.04 \pm 0.055 \mu \mathrm{g} / \mathrm{mL}$ ) on the viability of the cells, but rather increased the proliferation of the cells. This suggests that the extract is not harmful to healthy cells at concentrations between $100-200 \mu \mathrm{g} / \mathrm{mL}$ after 24,48 and $72 \mathrm{~h}$ of exposure. A similar study has also reported that G. africana was less effective in reducing the cell viability of non-malignant fibroblast and breast epithelial ( $\mathrm{IC}_{50}$ values of 185.5 and $159.8 \mu \mathrm{g} / \mathrm{mL}$ ), respectively [34]. While another study showed that G. africana was non-toxic as it did not induce a hypersensitivity response or cause any dermal sensitization to the epidermis [30]. These results suggest that G. africana can discriminate between malignant and non-malignant skin cells. Determining the possible cytotoxic effects of G. africana is important in understanding the therapeutic effects of anticancer drugs and its application in the development of new chemotherapeutic regimens which can lead to more effective melanoma treatments [36].

Studies show that the observed cytotoxicity of chemotherapeutic compounds often coincides with the induction of cell death [17]. This is a key characteristic of cells undergoing apoptosis, necrosis and other forms of programmed cell death [37-39]. Results of this study show that at higher doses $(500$ and $1000 \mu \mathrm{g} / \mathrm{mL})$ the percentage of cytotoxicity increased between 55-60\% in A375 cells. G. africana has been reported to also exhibit cytotoxicity on similar cancer cell lines ME1402 melanoma as well as breast cancer (MCF-7) [40]. However, the $\mathrm{HaCaT}$ cells only increased $(63 \%)$ in cytotoxicity at the highest concentration $(1000 \mu \mathrm{g} / \mathrm{mL})$ after $72 \mathrm{~h}$. This suggests that the extract was non-cytotoxic at the $500 \mu \mathrm{g} / \mathrm{mL}$ dosage on normal skin cells while being cytotoxic to cancer cells. This corroborates the anti-proliferative effects of the extracts to the metastatic melanoma cells. These results suggest that G. africana could be specific in its mechanism of targeting cancer cells while being non-toxic to healthy cells. This is a necessary aspect for the plant extract if it is to be viewed as a possible lead for drug development [35].

To investigate the possible cause of anti-proliferation activity, it was important to monitor the induction of cell death (apoptosis). Apoptosis can occur due to a genetically encoded suicide programme resulting in cellular, biochemical and morphological changes, including cell volume loss, chromatin condensation and nuclear fragmentation [17]. Regarding apoptotic induction, the direct mechanism was not completely understood or highlighted in this study as the analysis conducted did not extend that far. Hoechst staining proved 
that the G. africana induced more apoptotic features including nuclear shrinkage, condensation and fragmentation in A375 cells at higher concentrations (500 and $1000 \mu \mathrm{g} / \mathrm{mL}$ ) after 48 and $72 \mathrm{~h}$. The extract only displayed apoptotic features on the HaCaT cells at after longer exposure times at the highest concentration $(1000 \mu \mathrm{g} / \mathrm{mL})$. Results also support the notion that $G$. africana could potentially induce apoptosis in melanoma A375 cells. Research proposes that cellular apoptosis could be responsible for inhibiting proliferation of cultured cells and defects in apoptosis are important in the pathogenesis of melanoma [41]. According to Ravishankar et al. [42], plant flavonoids could interfere with multiple signal transduction pathways that limit proliferation, and metastasis or increase apoptosis. As previously stated, one of the major flavonoids found in G. africana is pinocembrin, with other secondary constituents of the plant being liquiritigenin and sakuranetin [21,24]. A study by Drira et al. [43] reported that sakuranetin decreases the rate of proliferation of B16 melanoma cells. Zheng et al. [44] and Rasul et al. [26] reported on the anti-proliferative effects of pinocembrin on melanoma cells (B16F10 and A375 cells) and other cancer cells such as colon and leukaemia. These studies found that pinocembrin can trigger apoptosis while suppressing autophagy in cancer cells. Pinocembrin also has the potential to inhibit, delay, block or reverse events associated with carcinogenesis. Other studies reported that the liquiritigenin flavanone could enhance the anti-migration and anti-invasion properties in B16F10 melanoma cells, as well as reduce cell viability, enhanced the apoptotic rate and induced LDH release in hepatocellular (HepG2) cells $[45,46]$. This further substantiates the extract's ability to differentiate between healthy and abnormal cells. G. africana could potentially be a supplementary agent that would mitigate the inadvertent cytotoxicity of chemotherapeutic agents to healthy skin cells.

Given that G. africana has been used traditionally for dermatological ailments, these components may require each other to work in synergy in treating human malignant melanoma, which is possibly why they have been effective as extracts in traditional medicine. The present study suggests that $G$. africana has the potential to inhibit proliferation and possibly induced apoptosis in melanoma cells. This indicates that the extract may be an effective complementary agent for the treatment of malignant melanoma.

\section{Conclusions}

The present study examined the growth inhibition of melanocytes and the noncytotoxic effects of ethanolic extracts from G. africana. This demonstrates that G. africana has selective growth inhibitory, including cytotoxic effects on the viability of A375 melanoma cells in comparison to normal HaCaT skin cells. These results warrant further studies on the underlying molecular mechanisms of the extract on A375 cells. This study shows that the G. africana ethanolic extract is a capable candidate for anti-melanoma agents, and provides new insights for future work on investigating the utilization of G. africana in malignant melanoma treatment for the potential to decrease cell viability and proliferation. Future studies will involve the detection of apoptotic markers to confirm whether the plant extract induces cell apoptosis and the anti-migration and anti-invasion properties of the G. africana extract.

Author Contributions: All authors listed made a substantial contribution to the manuscript and qualify for authorship. No authors have been omitted. Investigation, B.N.; writing—original draft preparation, B.N.; writing—review and editing, F.R., M.D.K., J.K., B.N.; supervision, F.R., M.D.K., J.K. All authors have read and agreed to the published version of the manuscript.

Funding: The authors greatly appreciate funding received by the National Research Foundation (NRF) South Africa for this study. Disclaimer: Any opinion, findings, and conclusions or recommendations expressed in this material are those of the authors and, therefore, the NRF does not accept any liability in regard thereto.

Institutional Review Board Statement: Not applicable.

Informed Consent Statement: Not applicable. 
Data Availability Statement: All data generated or analysed during this study are included in the article.

Acknowledgments: The authors would like to thank Astrid de Wet for assisting with some of the laboratory work.

Conflicts of Interest: The authors declare no conflict of interest.

\section{References}

1. Gelzo, M.; Granato, G.; Albano, F.; Arcucci, A.; Russo, A.D.; De Vendittis, E.; Ruocco, M.R.; Corso, G. Evaluation of cytotoxic effects of 7-dehydrocholesterol on melanoma cells. Free Radic. Biol. Med. 2014, 70, 129-140. [CrossRef] [PubMed]

2. Carr, S.; Smith, C.; Wernberg, J. Epidemiology and Risk Factors of Melanoma. Surg. Clin. 2020, 100, 1-12. [CrossRef] [PubMed]

3. Peng, X.; Wang, Z.; Liu, Y.; Peng, X.; Liu, Y.; Zhu, S.; Zhang, Z.; Qiu, Y.; Jin, M.; Wang, R. Oxyfadichalcone C inhibits melanoma A375 cell proliferation and metastasis via suppressing PI3K/Akt and MAPK/ERK pathways. Life Sci. 2018, 206, 35-44. [CrossRef] [PubMed]

4. Abildgaard, C.; Guldberg, P. Molecular drivers of cellular metabolic reprogramming in melanoma. Trends. Mol. Med. 2015, $21,164-171$. [CrossRef] [PubMed]

5. Rawson, R.V.; Scolyer, R.A. From Breslow to BRAF and immunotherapy: Evolving concepts in melanoma pathogenesis and disease progression and their implications for changing management over the last 50 years. Hum. Pathol. 2020, 95, 149-160. [CrossRef] [PubMed]

6. Agar, N.; Young, A.R. Melanogenesis: A photoprotective response to DNA damage? Mutat. Res. Fundam. Mol. Mech. Mutagenesis 2005, 571, 121-132. [CrossRef]

7. Prakash, O.; Kumar, A.; Kumar, P. Anticancer potential of plants and natural products. Am. J. Pharmacol. Sci. 2013, 1, 104-115. [CrossRef]

8. Force, J.; Salama, A.K. First-line treatment of metastatic melanoma: Role of nivolumab. Immuno Targets Ther. 2017, 6, 1. [CrossRef] [PubMed]

9. Niezgoda, A.; Niezgoda, P.; Czajkowski, R. Novel approaches to treatment of advanced melanoma: A review on targeted therapy and immunotherapy. BioMed. Res. Int. 2015, 2015. [CrossRef] [PubMed]

10. Ma, Q.; Shilkrut, M.; Zhao, Z.; Li, M.; Batty, N.; Barber, B. Autoimmune comorbidities in patients with metastatic melanoma: A retrospective analysis of us claims data. BMC Cancer 2018, 18, 145. [CrossRef] [PubMed]

11. Linardou, H.; Gogas, H. Toxicity management of immunotherapy for patients with metastatic melanoma. Ann. Transl. Med. 2016, 4 . [CrossRef] [PubMed]

12. Olver, I.; Carey, M.; Boyes, A.; Hall, A.; Noble, N.; Bryant, J.; Walsh, J.; Sanson-Fisher, R. The timeliness of patients reporting the side effects of chemotherapy. Support. Care Cancer 2018, 26, 3579-3586. [CrossRef]

13. Oun, R.; Moussa, Y.E.; Wheate, N.J. The side effects of platinum-based chemotherapy drugs: A review for chemists. Dalton Trans. 2018, 47, 6645-6653. [CrossRef]

14. Gaweł-Bęben, K.; Osika, P.; Asakawa, Y.; Antosiewicz, B.; Głowniak, K.; Ludwiczuk, A. Evaluation of anti-melanoma and tyrosinase inhibitory properties of marchantin A, a natural macrocyclic bisbibenzyl isolated from Marchantia species. Phytochem. Lett. 2019, 31, 192-195. [CrossRef]

15. De Silva, M.B.; Tencomnao, T. The protective effect of some Thai plants and their bioactive compounds in UV light-induced skin carcinogenesis. J. Photochem. Photobiol. B 2018, 185, 80-89. [CrossRef]

16. Khosravi, R.A.; Shokri, H.; Farahnejat, Z.; Chalangari, R.; Katalin, M. Antimycotic efficacy of Iranian medicinal plants towards dermatophytes obtained from patients with dermatophytosis. Chin. J. Nat. Med. 2013, 11, 43-48. [CrossRef]

17. George, V.C.; Kumar, D.N.; Suresh, P.; Kumar, R.A. Oleanolic acid inhibits cell growth and induces apoptosis in A375 melanoma cells. Biomed. Prev. Nutr. 2014, 4, 95-99. [CrossRef]

18. Watt, J.M.; Breyer-Brandwijk, M.G. The Medicinal and Poisonous Plants of Southern and Eastern Africa being an Account of their Medicinal and other Uses, Chemical Composition, Pharmacological Effects and Toxicology in Man and Animal. In The Medicinal and Poisonous Plants of Southern and Eastern Africa Being an Account of their Medicinal and Other Uses, Chemical Composition, Pharmacological Effects and Toxicology in Man and Animal; E. \& S. Livingstone Ltd.: Edinburgh, Scotland, 1962.

19. De Beer, J.J.; Van Wyk, B.-E. An ethnobotanical survey of the Agter-Hantam, Northern Cape Province, South Africa. S. Afr. J. Bot. 2011, 77, 741-754. [CrossRef]

20. Mativandlela, S.P.; Muthivhi, T.; Kikuchi, H.; Oshima, Y.; Hamilton, C.; Hussein, A.A.; van der Walt, M.L.; Houghton, P.J.; Lall, N. Antimycobacterial flavonoids from the leaf extract of Galenia africana. J. Nat. Prod. 2009, 72, 2169-2171. [CrossRef] [PubMed]

21. Ticha, L.A.; Klaasen, J.A.; Green, I.R.; Naidoo, S.; Baker, B.; Pietersen, R.-D. Phytochemical and Antimicrobial Screening of Flavanones and Chalcones from Galenia africana and Dicerothamnus rhinocerotis. Nat. Prod. Commun. 2015, 10, 1934578X1501000713. [CrossRef]

22. Panche, A.; Diwan, A.; Chandra, S. Flavonoids: An overview. J. Nutr. Sci. 2016, 5. [CrossRef]

23. Raffa, D.; Maggio, B.; Raimondi, M.V.; Plescia, F.; Daidone, G. Recent discoveries of anticancer flavonoids. Eur. J. Med. Chem. 2017, 142, 213-228. [CrossRef]

24. Vries, F.; El Bitar, H.; Green, I.; Klaasen, J.; Mabulesa, W.; Bodo, B.; Johnson, Q. An antifungal active extract from the aerial parts of Galenia africana. In Proceedings of the 11th NAPRECA, Antananarivo, Madagascar, 9-12 August 2005; pp. 123-131. 
25. Li, J.; Li, X.; Chen, Z.; Rasul, A.; Zhao, C.; Millimouno, F.M.; Tsuji, I.; Yamamura, T.; Iqbal, R.; Malhi, M. Antiproliferative and apoptotic effects of pinocembrin in human prostate cancer cells. Bangladesh J. Pharmacol. 2013, 8, 255-262.

26. Rasul, A.; Millimouno, F.M.; Ali Eltayb, W.; Ali, M.; Li, J.; Li, X. Pinocembrin: A novel natural compound with versatile pharmacological and biological activities. Biomed. Res. Int. 2013, 2013. [CrossRef]

27. Ng'uni, T. Medicinal Uses of Galenia africana: A Study of the Antimicrobial, Antifungal and Anticancer Properties. University of Western Cape: Bellville, South Africa, Unpublished work. 2017.

28. Alley, M.C.; Scudiero, D.A.; Monks, A.; Hursey, M.L.; Czerwinski, M.J.; Fine, D.L.; Abbott, B.J.; Mayo, J.G.; Shoemaker, R.H.; Boyd, M.R. Feasibility of drug screening with panels of human tumor cell lines using a microculture tetrazolium assay. Cancer Res. 1988, 48, 589-601. [PubMed]

29. Fotakis, G.; Timbrell, J.A. In vitro cytotoxicity assays: Comparison of LDH, neutral red, MTT and protein assay in hepatoma cell lines following exposure to cadmium chloride. Toxicol. Lett. 2006, 160, 171-177. [CrossRef] [PubMed]

30. Ng'uni, T.; Klaasen, J.A.; Fielding, B.C. Acute toxicity studies of the South African medicinal plant Galenia africana. Toxicol. Rep. 2018, 5, 813-818. [CrossRef]

31. Van Wyk, B.-E.; De Wet, H.; Van Heerden, F. An ethnobotanical survey of medicinal plants in the Southeastern Karoo, South Africa. S. Afr. J. Bot. 2008, 74, 696-704. [CrossRef]

32. Ghosh, S.; Bishayee, K.; Khuda-Bukhsh, A.R. Oleanolic acid isolated from ethanolic extract of Phytolacca decandra induces apoptosis in A375 skin melanoma cells: Drug-DNA interaction and signaling cascade. J. Integr. Med. 2014, 12, 102-114. [CrossRef]

33. Abotaleb, M.; Samuel, S.M.; Varghese, E.; Varghese, S.; Kubatka, P.; Liskova, A.; Büsselberg, D. Flavonoids in cancer and apoptosis. Cancers 2019, 11, 28. [CrossRef]

34. Mohamed, L.; Chakraborty, S.; ArulJothi, K.N.; Mabasa, L.; Sayah, K.; Costa-Lotufo, L.V.; Jardine, A.; Prince, S. Galenia africana plant extract exhibits cytotoxicity in breast cancer cells by inducing multiple programmed cell death pathways. Saudi Pharm. J. 2020, 28, 1155-1165. [CrossRef] [PubMed]

35. Mativandlela, S.P.N.; Meyer, J.J.M.; Hussein, A.A.; Houghton, P.J.; Hamilton, C.J.; Lall, N. Activity against Mycobacterium smegmatis and M. tuberculosis by extract of South African medicinal plants. Phytother. Res. 2008, 22, 841-845. [CrossRef]

36. Powis, G. Dose-dependent metabolism, therapeutic effect, and toxicity of anticancer drugs in man. Drug Metab. Rev. 1983, 14, 1145-1163. [CrossRef] [PubMed]

37. Abdullah, A.-S.H.; Mohammed, A.S.; Abdullah, R.; Mirghani, M.E.S.; Al-Qubaisi, M. Cytotoxic effects of Mangifera indica L. kernel extract on human breast cancer (MCF-7 and MDA-MB-231 cell lines) and bioactive constituents in the crude extract. BMC Compl. Altern. Med. 2014, 14, 199. [CrossRef]

38. Kadan, S.; Saad, B.; Sasson, Y.; Zaid, H. In vitro evaluations of cytotoxicity of eight antidiabetic medicinal plants and their effect on GLUT4 translocation. Evid. Based Complement. Altern. Med. 2013, 2013. [CrossRef] [PubMed]

39. Specian, A.F.L.; Serpeloni, J.M.; Tuttis, K.; Ribeiro, D.L.; Cilião, H.L.; Varanda, E.A.; Sannomiya, M.; Martinez-Lopez, W.; Vilegas, W.; Cólus, I.M. LDH, proliferation curves and cell cycle analysis are the most suitable assays to identify and characterize new phytotherapeutic compounds. Cytotechnology 2016, 68, 2729-2744. [CrossRef]

40. Barry, M.-J.J. Compositions Derived from Galenia Africana and Methods of Use for Cancer Treatment. U.S. Patents 20190365840A1, 12 December 2019.

41. Pang, W.; Liu, S.; He, F.; Li, X.; Saira, B.; Zheng, T.; Chen, J.; Dong, K.; Pei, X.-F. Anticancer activities of Zanthoxylum bungeanum seed oil on malignant melanoma. J. Ethnopharmacol. 2019, 229, 180-189. [CrossRef]

42. Ravishankar, D.; Rajora, A.K.; Greco, F.; Osborn, H.M. Flavonoids as prospective compounds for anti-cancer therapy. Int. J. Biochem. Cell Biol. 2013, 45, 2821-2831. [CrossRef]

43. Drira, R.; Sakamoto, K. Sakuranetin induces melanogenesis in B16BL6 melanoma cells through inhibition of ERK and PI3K/AKT signaling pathways. Phytother. Res. 2016, 30, 997-1002. [CrossRef] [PubMed]

44. Zheng, Y.; Wang, K.; Wu, Y.; Chen, Y.; Chen, X.; Hu, C.W.; Hu, F. Pinocembrin induces ER stress mediated apoptosis and suppresses autophagy in melanoma cells. Cancer Lett. 2018, 431, 31-42. [CrossRef]

45. Shi, H.; Wu, Y.; Wang, Y.; Zhou, M.; Yan, S.; Chen, Z.; Gu, D.; Cai, Y. Liquiritigenin potentiates the inhibitory effects of cisplatin on invasion and metastasis via downregulation MMP-2/9 and PI3 K/AKT signaling pathway in B16F10 melanoma cells and mice model. Nutr. Cancer 2015, 67, 761-770. [CrossRef] [PubMed]

46. Wang, D.; Lu, J.; Liu, Y.; Meng, Q.; Xie, J.; Wang, Z.; Teng, L. Liquiritigenin induces tumor cell death through mitogen-activated protein kinase-(MPAKs-) mediated pathway in hepatocellular carcinoma cells. Biomed. Res. Int. 2014, 2014. [CrossRef] [PubMed] 